\title{
RISK ASSESSMENT K3 PADA PROSES PENGOPERASIAN SCAFFOLDING PADA PROYEK APARTEMEN PT. X DI SURABAYA
}

\author{
Yudha Bagus Persada \\ Persatuan Alumni Kesehatan Masyarakat Indonesia (PERSAKMI) Provinsi Jawa Timur \\ E-mail: yudhapersada@gmail.com
}

\begin{abstract}
Problems that arised when employees works at height are worker did not wear full body harness, lanyard did not hanged perfectly to handrail, did not works according to the procedure, and using unsafe scaffolding. Hazard identification and risk assessment used as prevention for accident when operating scaffolding. This study was an observational study with cross sectional design and analyzed descriptively. The design used for the study carried out by observing cause and effect within a period of time and space. Objects of this study were frame scaffolding and scaffolding PCH, while subjects of this study were SHE Officer, SHE supervisor, workers section structure, finishing, plumbing hydrant, and mechanical engineering. Results of hazard identification using JSA method founds 43 potential hazards originating from 4 different types of work in this project. The results of the risk assessment of 43 potential hazards have been found that 1 hazard have low risk, 40 hazards have moderate risk, and high risk hazard are 2. The dominant risk from the operation of the scaffolding was 40 potential hazards or 93\% of the total potential hazards and high-risk hazard eventhough only $5 \%$ of all potential hazards remains a top priority and should be controlled soon to reduce the high and medium risk becomes low risk. The likelihood-based control is more possible to reduce risk level than severity-based control.
\end{abstract}

Keywords: risk assessment, scaffolding operation

\begin{abstract}
ABSTRAK
Masalah yang timbul ketika pekerja bekerja di ketinggian, diantaranya pekerja tidak menggunakan Full Body Harness, lanyard tidak dikaitkan dengan sempurna ke handrail, bekerja tidak mematuhi prosedur yang ada, scaffolding atau perancah yang tidak aman digunakan. Hazard identification and risk assessment dilakukan sebagai pencegahan terjadinya kecelakaan pada pengoperasian scaffolding. Penelitian ini merupakan penelitian observasional dengan desain cross sectional dan dianalisis secara deskriptif. Desain tersebut digunakan karena penelitian dilakukan dengan cara mengamati sebab akibat dalam satu periode ruang dan waktu. Objek dalam penelitian ini adalah scaffolding frame dan scaffolding $P C H$, sedangkan subjek dalam penelitian ini adalah SHE officer, SHE supevisor, pekerja bagian struktur, finishing, plumbing hydrant, dan mechanical engineering. Hasil hazard identification menggunakan metode JSA dihasilkan 43 temuan potensi bahaya dan potensi kegagalan yang berasal dari 4 jenis pekerjaan pada proyek. Hasil risk assessment terhadap 43 potensi bahaya yang telah ditemukan didapati 1 bahaya memiliki risiko rendah, 40 bahaya memiliki risiko sedang, dan 2 bahaya memiliki risiko tinggi. Risiko yang dominan pada pengoperasian scaffolding yaitu risiko sedang dengan 40 potensi bahaya atau 93\% dari total potensi bahaya dan risiko tinggi meskipun hanya 5\% dari seluruh potensi bahaya tetap sebagai prioritas utama yang ada sehingga harus segera dilakukan pengendalian untuk menurunkan risiko tinggi dan sedang tersebut menjadi risiko rendah. Pengendalian berbasis likelihood lebih mungkin diterapkan untuk mengurangi tingkat risiko dibandingkan dengan pengendalian berbasis severity.
\end{abstract}

Kata kunci: risk assessment, pengoperasian scaffolding

\section{PENDAHULUAN}

Bahaya sangat berkaitan dengan risiko, agar dapat lebih memahami risiko, maka harus memahami dengan arti dari bahaya. Bahaya didefinisikan oleh Frank Bird sebagai sumber yang dapat mencelakakan manusia, merusak fasilitas, lingkungan dan atau kombinasi dari hal-hal tersebut, sedangkan menurut (OHSAS 18001, 2007), bahaya merupakan sumber, situasi, atau tindakan dengan potensi yang dapat menimbulkan luka dan sakitnya manusia.
Bahaya merupakan situasi yang berpotensi menimbulkan cidera atau kerusakan pada manusia, bahaya sangat alamiah dan melekat pada zat, sistem, atau peralatan. Contoh bahaya adalah seperti panas pada api, dingin pada es, bahaya kecepatan tumbukan pada kendaraan bermotor. Bahaya tidak dapat dihilangkan tetapi dapat dikendalikan (Ramli, 2010).

Bahaya dan risiko sangat berhubungan dan saling mempengaruhi, risiko seperti katalis bagi sebuah bahaya (hazard) untuk menjadi sebuah 
kecelakaan. Contoh mudahnya adalah peralatan drilling sangat berat dan itu termasuk bahaya, akan tetapi apabila dipasang dan diperlakukan dengan benar maka risiko dari drill untuk mencelakakan proses kerja dan manusia akan menjadi rendah, berbeda dengan apabila risiko yang ada tidak dikendalikan dengan baik maka kemungkinan besar bahaya yang ada akan mencelakakan pekerja.

Risiko merupakan hal yang tidak bisa lepas dari kehidupan manusia sehari-hari, risiko tidak mungkin dapat dihilangkan, namun dapat diminimalisasi dengan adanya proses risk management. Setiap hal yang manusia lakukan pasti mengandung risiko, bahkan apabila sedang jalan santai di depan rumah tetap ada risiko, seperti contohnya tidak sengaja tertabrak motor atau sepeda motor, namun risiko tertabrak tersebut dapat diminimalisir dengan berjalan tidak terlalu ke tengah, selalu waspada dengan keadaan sekitar, tetap fokus. Solusi dapat ditentukan dari risiko tersebut dengan sebelumnya menilai semua bahaya yang ada dan tingkat bahayanya, seperti motor yang melintas tiba-tiba bahayanya seberapa besar, berjalan terlalu ke tengah bahayanya seberapa besar, dan apabila kurang fokus bahayanya seberapa besar, penilaian inilah yang dimaksud dengan risk assessment.

Risk assessment terdiri dari 3 tahap, yaitu hazard identification, analisa risiko dan evaluasi risiko. Analisa risiko untuk menentukan besarnya risiko yang dicerminkan dan menilai seberapa besar derajat keparahannya. Analisa risiko biasa menggunakan 3 teknik, yaitu teknik kualitatif, teknik semi kuantitatif, dan teknik kuantitatif, sedangkan evaluasi risiko adalah menentukan risiko yang ada dapat diterima atau harus segera dilakukan pengendalian untuk mengurangi tingkat risiko yang ada (Ramli, 2010).

Hira (Hazzard Identification and Risk Assessment) merupakan suatu metode atau teknik untuk mengidentifikasi potensi bahaya kerja dengan mendefinisikan karakteristik bahaya yang mungkin terjadi dan mengevaluasi risiko yang terjadi melalui penilaian risiko dengan menggunakan matriks penilaian risiko (Susihono, 2013).

Kecelakaan kerja paling sering terjadi pada bidang konstruksi. Kecelakaan kerja pada bidang konstruksi sebagian besar disebabkan oleh tenaga kerja yang kurang berpengalaman terhadap bidang yang dikerjakannya, kondisi lingkungan yang tidak aman, menggunakan peralatan yang tidak sesuai dengan fungsinya, kurangnya kepedulian pekerja terhadap safety, dan manajemen perusahaan yang masih kurang baik terhadap safety. (Dewobroto dalam Wahyuni, 2010).

Sektor konstruksi menyumbang sekitar 32\% dari total angka kecelakaan kerja di Indonesia, nilai tersebut merupakan angka tertinggi dibandingkan dengan sektor lain. Angka tersebut juga termasuk tinggi jika dibandingkan dengan angka penyerapan tenaga kerja pada bidang konstruksi, karena angka penyerapan tenaga kerja pada bidang konstruksi hanya $5 \%$ dari total tenaga kerja di Indonesia. (Pratiwi, 2009)

Pekerjaan konstruksi adalah pekerjaan yang padat karya dengan level risiko yang cukup tinggi, misalnya pada pengangkatan benda berat, bekerja pada ketinggian, serta bekerja pada ruang terbatas. Efek dari kecelakaan pada pekerjaan tersebut, antara lain adalah rusaknya peralatan yang digunakan, rusaknya lingkungan sekitar proyek, serta fatality atau hilangnya nyawa pekerja. Secara keseluruhan efek-efek tersebut akan mempengaruhi jadwal penyelesaian project, serta pembengkakan pada biaya konstruksi (Dewobroto dalam Wahyuni, 2010).

Salah satu pekerjaan yang banyak mengalami kecelakaan kerja adalah pekerjaan pada ketinggian, banyak masalah yang timbul ketika pekerja bekerja di ketinggian misalnya pekerja tidak menggunakan alat pelindung diri (Full Body Harness), lanyard tidak dikaitkan dengan sempurna ke handrail, bekerja tidak mematuhi prosedur yang ada, scaffolding atau perancah yang tidak aman digunakan. Menurut data, diperkirakan 2,3 juta dari pekerja konstruksi atau 65 persen dari seluruh pekerja industri konstruksi, bekerja pada scaffolding atau perancah. Bahkan dalam sebuah studi yang telah dilakukan oleh Biro Statistik Tenaga Kerja, 72 persen pekerja terluka dalam kecelakaan yang terjadi pada scaffolding yang disebabkan karena papan tempat mereka berpijak atau tertimpa bahan yang jatuh dari atas perancah (Prasetiyo, 2009).

Menurut Permenaker No. 01/Men/1980 tentang keselamatan dan kesehatan kerja pada konstruksi bangunan, perancah atau scaffolding yang digunakan harus benar-benar aman dan sesuai. Perancah atau scaffolding juga harus diberikan pagar pengaman (railing), sedangkan scaffolding yang ada pada proyek ini tidak menggunakan railing hampir di semua scaffolding yang digunakan, padahal ketinggian dari tempat kerja sangat beragam dan bisa mencapai ketinggian lantai 20 keatas, hal ini tentu sangat membahayakan pekerjaan yang dilakukan oleh pekerja. 
Proyek ini juga tidak memiliki scaffolder khusus yang bertugas untuk memasang, merawat, memelihara dan membongkar scaffolding yang memiliki sertifikat supervisor perancah dari Kemenakertrans seperti yang diatur dalam Surat Keputusan Dirjen PPK No. 20/DJPPK/2004. Hal ini menyebabkan proses pemasangan hingga pembongkaran scaffolding sangat berisiko karena dilakukan oleh orang yang tidak ahli untuk memasang dan membongkar scaffolding.

Kecelakaan yang paling sering terjadi pada scaffoding di proyek ini adalah pekerja terbentur, terjepit pada saat pemasangan dan pembongkaran, serta tertimpa material yang jatuh. Pada tanggal 10 Mei 2015 juga terjadi kecelakaan kerja di tempat penelitian yang berhubungan dengan perancah, yaitu kepala pekerja tertimpa komponen perancah pada saat pembongkaran sehingga pekerja harus dilarikan ke rumah sakit.

Tujuan dari penelitian ini adalah menilai risiko yang ada pada pengoperasian scaffolding proyek Apartemen PT. X di Surabaya.

\section{METODE}

Ditinjau dari jenis penelitiannya, maka penelitian ini termasuk penelitian observasional, karena peneliti tidak memberikan perlakuan apa pun dan hanya mengamati objek. Dilihat dari sistem analisisnya termasuk penelitian deskriptif, karena penelitian dilakukan dengan tujuan utama untuk membuat gambaran tentang suatu keadaan secara obyektif. Rancangan penelitian ini apabila dilihat dari segi ruang waktu, maka termasuk penelitian cross sectional, karena pengamatan terhadap variabel dilakukan pada satu periode sekaligus.

Objek penelitian ini adalah proses pengoperasian scaffolding yang digunakan pada Proyek Apartemen yang dikerjakan oleh PT. X. Penelitian juga dilakukan dengan cara observasi pada proses pengoperasian scaffolding di area Apartemen pada pekerjaan struktur, finishing, plumbing hydrant, dan mechanical engineering bersama dengan SHE Officer dan SHE Supervisor untuk mendapatkan data primer. Subjek penelitian ini adalah SHE Officer, SHE Supervisor, dan Pekerja yang ada di proyek tersebut. Dilakukan wawancara dengan SHE Officer dan SHE Supervisor karena dianggap paling bertanggung jawab terhadap kesehatan dan keselamatan kerja yang ada pada proyek ini.

Lokasi Penelitian pada Proyek Apartemen Surabaya yang dikerjakan oleh perusahaan bidang konstruksi PT. X. Waktu pengambilan data dari penelitian ini adalah pada bulan Mei 2015.

Komponen penelitian ini terdiri atas risk assessment pada pekerjaan struktur, finishing, plumbing hydrant, mechanical engineering. Data didapatkan dari hasil observasi dan wawancara dengan subjek penelitian.

Hasil analisis risk assessment diolah secara deskriptif yaitu menyajikan data dalam bentuk tabel maupun narasi sehingga mempermudah pemahaman hasil penelitian.

\section{HASIL}

\section{Hazard Identification Pekerjaan Struktur}

Pekerjaan struktur terdiri atas dua langkah kerja, yaitu perakitan scaffolding $P C H$ dan pembongkaran scaffolding $P C H$. Scaffolding $P C H$ ini digunakan untuk menopang struktur di atasnya hingga pengecoran selesai dilakukan dan dilakukan pembongkaran scaffolding PCH. scaffolding PCH hampir digunakan di semua konstruksi besar saat akan menambah jumlah lantai di atasnya.

Hasil dari identifikasi bahaya pada pekerjaan struktur didapati pada langkah kerja perakitan scaffolding $P C H$ terdapat 5 potensi bahaya, yaitu low back pain yang disebabkan karena postur kerja yang tidak sesuai karena terlalu menunduk saat bekerja menggunakan scaffolding, tangan terjepit yang disebabkan oleh pekerja yang tidak berhatihati saat bekerja, tertimpa material yang disebabkan oleh material tidak dalam posisi yang pas dan cara pemasangan yang salah, kepala terbentur yang disebabkan karena pekerja tidak waspada, dan kaki tersandung material yang disebabkan karena tidak waspada dalam bekerja dan material yang berserakan.

Pada langkah kerja pembongkaran scaffolding $P C H$ terdapat 4 potensi bahaya yaitu kepala terbentur yang disebabkan karena pekerja tidak waspada, tertimpa material yang disebabkan karena material tidak dalam posisi yang seharusnya dan cara pembongkaran yang salah, terpeleset yang disebabkan karena lantai dalam kondisi licin karena air bekas cor, dak kebisingan yang disebabkan oleh suara material scaffolding yang berjatuhan.

\section{Hazard Identification Pekerjaan Finishing}

Pekerjaan finishing terdiri atas empat langkah kerja, yaitu pemasangan bata ringan, pengecoran 
kolom praktis, plester untuk tembok, dan pengacian tembok.

Langkah kerja pemasangan bata ringan mengandung 4 potensi bahaya, yaitu terpeleset yang disebabkan karena platform licin dan besi terkena semen, terjatuh yang disebabkan karena pekerja tidak menggunakan full body harness dan cross brace tidak sempurna, kepala terbentur yang disebabkan karena pekerja tidak menggunakan safety helmet dan tidak waspada, dan gangguan pernapasan yang disebabkan oleh debu semen dan debu dari pasir.

Langkah kerja pengecoran kolom praktis mengandung 4 potensi bahaya, yaitu terpeleset yang disebabkan oleh platform yang licin dan besi terkena semen, terjatuh yang disebabkan pekerja tidak menggunakan full body harness dan cross brace tidak sempurna, kepala terbentur yang disebabkan karena pekerja tidak menggunakan safety helmet dan tidak waspada, dan gangguan pernapasan yang disebabkan oleh debu semen dan debu pasir.

Langkah kerja plester mengandung 4 potensi bahaya, yaitu terpeleset yang disebabkan oleh platform yang licin dan besi terkena semen, terjatuh yang disebabkan karena pekerja tidak menggunakan full body harness dan cross brace tidak sempurna, terbentur yang disebabkan karena pekerja tidak menggunakan safety helmet dan tidak waspada, gangguan pernapasan yang disebabkan karena debu semen dan debu pasir.

Langkah kerja pengacian mengandung 4 potensi bahaya, yaitu terpeleset yang disebabkan oleh platform yang licin dan besi terkena semen, terjatuh yang disebabkan karena pekerja tidak menggunakan full body harness dan cross brace tidak sempurna, kepala terbentur yang disebabkan karena pekerja tidak menggunakan safety helmet dan tidak waspada, dan gangguan pernapasan yang disebabkan oleh debu semen dan debu pasir.

\section{Hazard Identification Pekerjaan Plumbing Hydrant}

Pekerjaan plumbing hydrant terdiri atas tiga langkah kerja, yaitu pengangkatan material berupa pipa besi dari bawah ke atas scaffolding, kemudian perakitan perpipaan di langit-langit gedung, dan yang terakhir adalah pengelasan dari pipa hydrant yang telah dirakit.

Langkah kerja pengangkatan material mengandung 2 potensi bahaya, yaitu low back pain yang disebabkan karena postur kerja yang kurang ergonomis dan terpeleset yang disebabkan karena main frame yang licin dan sepatu pekerja yang tidak sempurna.

Langkah kerja perakitan perpipaan hydrant mengandung 2 potensi bahaya, yaitu terpeleset yang disebabkan karena main frame yang licin dan sepatu pekerja yang tidak sempurna dan terjatuh yang disebabkan karena tidak menggunakan full body harness dan cross brace tidak terpasang sempurna.

Langkah kerja pengelasan dan penyambungan pipa hydrant mengandung 4 potensi bahaya, yaitu low back pain yang disebabkan oleh postur kerja yang kurang ergonomis, terpeleset yang disebabkan karena main frame yang licin dan sepatu pekerja yang tidak sempurna, terjatuh yang disebabkan karena pekerja tidak menggunakan full body harness dan cross brace tidak terpasang sempurna, dan terbakar karena pada saat pengelasan perpipaan pekerja tidak menggunakan face mask dan safety gloves.

\section{Hazard Identification Pekerjaan Mechanical Engineering}

Pekerjaan mechanical engineering adalah pekerjaan yang menangani seluruh kelistrikan pada proyek dan apartemen setelah apartemen siap huni nanti, pekerjaan mechanical engineering terdiri atas 3 langkah kerja, yaitu penentuan titik di mana akan dirakit jaringan-jaringannya nantinya, pemasangan jaringan kelistrikan, dan langkah terakhir adalah perakitan kabel.

Langkah kerja penentuan titik mengandung 3 potensi bahaya, yaitu low back pain yang disebabkan posisi kerja yang kurang ergonomis, terjatuh yang disebabkan karena main frame licin, tidak menggunakan full body harness dan cross brace tidak sempurna, dan terbentur yang disebabkan karena Tidak menggunakan safety helmet dan tidak waspada.

Langkah kerja pemasangan jaringan mengandung 4 potensi bahaya, yaitu low back pain yang disebabkan oleh posisi kerja yang kurang ergonomis, terjatuh yang disebabkan karena main frame licin, tidak menggunakan full body harness dan cross brace tidak sempurna, gangguan pernapasan yang disebabkan oleh debu dan tidak menggunakan respirator, dan terbentur yang disebabkan karena tidak menggunakan safety helmet dan tidak waspada.

Langkah kerja terakhir perakitan kabel mengandung 3 potensi bahaya, yaitu low back pain yang disebabkan karena posisi kerja yang kurang ergonomis, terjatuh yang disebabkan karena main 
frame licin, tidak menggunakan full body harness dan cross brace tidak sempurna, dan terbentur yang disebabkan karena pekerja tidak menggunakan safety helmet dan tidak waspada dalam bekerja.

\section{Risk Assessment Pekerjaan Struktur}

Pekerjaan struktur terdiri dari 2 langkah kerja yaitu perakitan scaffolding $P C H$ dan pembongkaran scaffolding $P C H$.

Langkah kerja perakitan scaffolding $P C H$ mengandung 5 potensi bahaya yaitu low back pain dengan skor likelihood 5, severity 1, dan risk rating sebesar 5, kemudian bahaya tangan terjepit dengan nilai likelihood 4, severity 2, dan risk rating 8 , bahaya tertimpa material dengan likelihod 4 , severity 3 , dan risk rating 12 , bahaya kepala terbentur dengan nilai likelihood 5 , severity 1 , dan risk rating sebesar 5 , dan yang terakhir bahaya tersandung material yang memiliki nilai likelihod 4 , severity 1 , dan risk rating sebesar 4 .

Langkah kerja yang kedua yaitu pembongkaran scaffolding $P C H$ yang mengandung 4 bahaya yaitu kepala terbentur dengan nilai likelihood 5 , severity 1 , dan risk rating sebesar 5, bahaya tertimpa material dengan likelihod 4 , severity 3 , dan risk rating 12 , bahaya terpeleset dengan likelihood 3 , severity 2 , dan risk rating sebesar 6 , dan terakhir bahaya kebisingan dengan nilai likelihod 5 , severity 1 , dan risk rating sebesar 5 .

\section{Risk Assessment Pekerjaan Finishing}

Pekerjaan finishing terdiri dari 4 langkah kerja yaitu pemasangan bata ringan, pengecoran kolom praktis, plester, dan pengacian.

Langkah kerja pemasangan bata ringan mengandung 4 bahaya, yaitu terpeleset dengan likelihood 3, severity 2, dan risk rating sebesar 6 , bahaya terjatuh dengan nilai likelihood 2, severity 4 , dan risk rating sebesar 8 , bahaya kepala terbentur dengan nilai likelihood 5 , severity 1 , dan risk rating sebesar 5, dan bahaya gangguan pernapasan dengan likelihood 5, severity 1 , dan risk rating sebesar 5 .

Langkah kerja pengecoran kolom praktis mengandung 4 potensi bahaya yaitu terpeleset dengan likelihood 3 , severity 2 , dan risk rating sebesar 6, bahaya terjatuh dengan nilai likelihood 2 , severity 4 , dan risk rating sebesar 8 , bahaya terbentur dengan nilai likelihood 5 , severity 1 , dan risk rating sebesar 5, dan bahaya gangguan pernapasan dengan likelihood 5 , severity 1 , dan risk rating sebesar 5 .

Langkah kerja plester mengandung 4 bahaya yaitu terpeleset dengan likelihood 3 , severity 2 , dan risk rating sebesar 6 , bahaya terjatuh dengan nilai likelihood 2, severity 4, dan risk rating sebesar 8, bahaya terbentur dengan nilai likelihood 5 , severity 1 , dan risk rating sebesar 5 , dan bahaya gangguan pernapasan dengan likelihood 5, severity 1, dan risk rating sebesar 5 .

Langkah kerja pengacian mengandung 4 bahaya, yaitu terpeleset dengan likelihood 3, severity 2, dan risk rating sebesar 6 , bahaya terjatuh dengan nilai likelihood 2, severity 4, dan risk rating sebesar 8, bahaya terbentur dengan nilai likelihood 5 , severity 1 , dan risk rating sebesar 5 , dan bahaya gangguan pernapasan dengan likelihood 5, severity 1, dan risk rating sebesar 5 .

\section{Risk Assessment Pekerjaan Plumbing Hydrant}

Pekerjaan plumbing hydrant terdiri dari 3 langkah kerja yaitu pengangkatan material, perakitan perpipaan hydrant, dan pengelasan dan penyambungan pipa hydrant.

Langkah kerja pengangkatan material mengandung 2 bahaya yaitu low back pain dengan skor likelihood 5 , severity 1 , dan risk rating sebesar 5, dan bahaya terpeleset dengan likelihood 3, severity 2, dan risk rating sebesar 6 .

Langkah kerja perakitan perpipaan hydrant mengandung 2 bahaya yaitu terpeleset dengan likelihood 3, severity 2 , dan risk rating sebesar 6 , dan bahaya terjatuh dengan nilai likelihood 2, severity 4 , dan risk rating sebesar 8 .

Langkah kerja pengelasan dan penyambungan pipa hydrant mengandung 4 bahaya, yaitu low back pain dengan skor likelihood 5, severity 1, dan risk rating sebesar 5, bahaya terpeleset dengan likelihood 3 , severity 2 , dan risk rating sebesar 6 , bahaya terjatuh dengan nilai likelihood 2 , severity 4 , dan risk rating sebesar 8 , dan bahaya terbakar dengan likelihood 4 , severity 2 , dan risk rating sebesar 8 .

\section{Risk Assessment Pekerjaan Mechanical Engineering}

Pekerjaan mechanical engineering terdiri dari 3 langkah kerja yaitu penentuan titik, pemasangan jaringan, dan perakitan kabel.

Pada langkah kerja penentuan titik terdapat 3 bahaya yaitu low back pain dengan skor likelihood 5 , severity 1 , dan risk rating sebesar 5, bahaya terjatuh dengan nilai likelihood 2 , severity 4 , dan risk rating sebesar 8 , dan bahaya terbentur dengan nilai likelihood 5, severity 1, dan risk rating sebesar 5 .

Pada langkah kerja pemasangan jaringan terdapat 4 potensi bahaya, yaitu low back pain 
dengan skor likelihood 5 , severity 1 , dan risk rating sebesar 5, bahaya terjatuh dengan nilai likelihood 2 , severity 4 , dan risk rating sebesar 8 , bahaya gangguan pernapasan dengan likelihood 5 , severity 1 , dan risk rating sebesar 5, dan bahaya terbentur dengan nilai likelihood 5, severity 1 , dan risk rating sebesar 5 .

Langkah kerja terakhir yaitu langkah kerja perakitan kabel mengandung 3 bahaya, yaitu low back pain dengan skor likelihood 5 , severity 1 , dan risk rating sebesar 5 , bahaya terjatuh dengan nilai likelihood 2 , severity 4 , dan risk rating sebesar 8 , dan bahaya terbentur dengan nilai likelihood 5, severity 1, dan risk rating sebesar 5 .

\section{Kategori Risiko yang Paling Dominan}

Hasil rekapitulasi risk assessment dalam bentuk diagram sebagai gambaran kategori risiko yang paling dominan dalam proses pengoperasian scaffolding pada proyek pembangunan apartemen PT. X. akan disajikan pada gambar 1.

Didapati bahwa risiko yang paling dominan adalah risiko kategori sedang dengan $93 \%$ dari total bahaya yang ada, diikiti dengan kategori risiko tinggi sebesar $5 \%$, dan yang paling kecil adalah kategori risiko rendah sebesar $2 \%$ dari total bahaya yang ada.

\section{Kategori Risiko}

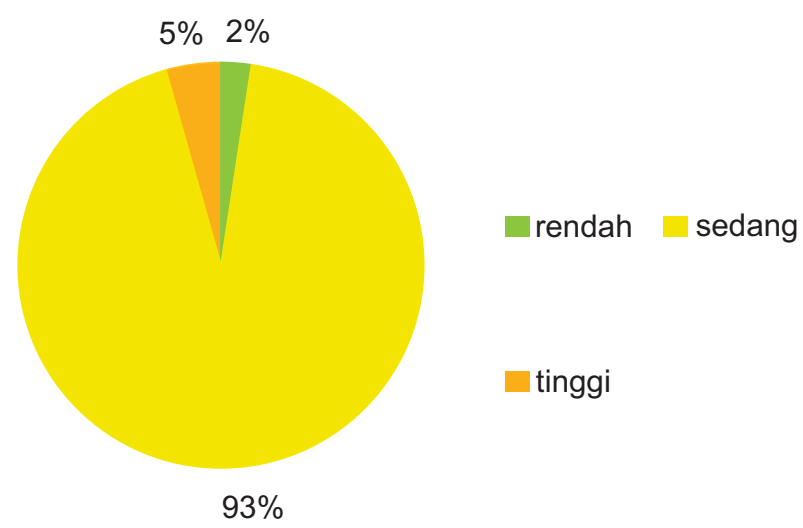

Gambar 1. Kategori Risiko yang Paling Dominan

\section{PEMBAHASAN}

\section{Hazard Identification Pekerjaan Struktur}

Terdapat dua langkah kerja dalam pekerjaan struktur yang masing-masing memiliki potensi bahaya, yaitu perakitan scaffolding $P C H$ dan pembongkaran scaffolding $P C H$. Berikut adalah pembahasan identifikasi bahaya pada pekerjaan struktur:

\section{Perakitan scaffolding PCH (Perth Construction Hire)}

Bahaya mekanik yang teridentifikasi pada perakitan scaffolding $\mathrm{PCH}$ adalah tangan terjepit, tertimpa material, kepala terbentur, dan tersandung material. Penyebab dari tangan terjepit ialah karena tidak berhati-hati dan tidak fokus saat merakit scaffolding PCH. Penyebab tertimpa material adalah karena pada saat membawa material keatas kurang berhati-hati sehingga menimpa rekan kerja yang berada di bawah. Penyebab kepala terbentur adalah tidak menggunakan safety helmet saat bekerja dan kurang waspada. Penyebab tersandung material karena material penyusun scaffolding $P C H$ dibiarkan berserakan tanpa pengawasan yang cukup dan kurangnya fokus dari pekerja.

Bahaya ergonomi yang teridentifikasi adalah low back pain yang disebabkan postur kerja yang tidak sesuai. Pada saat mengangkat material penyusun scaffolding pekerja biasanya tidak menerapkan prosedur lifting yang tepat dan biasanya mengangkat dengan membungkuk, hal ini dapat menyebabkan terjadinya keluhan punggung.

\section{Pembongkaran Scafolding PCH (Perth Construction Hire)}

Bahaya mekanik yang teridentifikasi dalam pembongkaran scaffolding $P C H$ ini adalah terbentur, tertimpa material, dan terpeleset. Penyebab terbentur adalah karena tidak waspada dan tidak menggunakan safety helmet dalam bekerja. Penyebab tertimpa material adalah karena kurang hati-hati dalam membongkar komponen penyusun scaffolding sehingga menimpa bagian tubuh rekan kerjanya. Penyebab terpeleset karena lantai dalam kondisi licin yang disebabkan air genangan bekas cor dari lantai atasnya, pembongkaran ini dilakukan saat pengecoran sudah selesai.

Bahaya fisik yang terdapat pada pembongkaran scaffolding $\mathrm{PCH}$ ini adalah kebisingan, hal ini disebabkan karena pada saat dibongkar material dibiarkan jatuh begitu saja ke lantai dan hal tersebut menimbulkan suara yang bising.

\section{Hazard Identification Pekerjaan Finishing}

Pekerjaan finisihing terdiri dari 4 langkah kerja, yaitu pemasangan bata ringan, pengecoran kolom praktis, plester, dan pengacian. Bahaya yang teridentifikasi pada masing-masing langkah kerja adalah sebagai berikut: 


\section{Pemasangan bata ringan}

Bahaya mekanis yang teridentifikasi pada pemasangan bata ringan yaitu terpeleset, terjatuh, dan terbentur. Penyebab dari terpeleset adalah platform yang licin akibat terkena semen, pekerja yang tidak berhati-hati bisa saja terpeleset. Penyebab dari terjatuh adalah tidak menggunakan body harness pada saat bekerja dan cross brace tidak dipasang secara lengkap. Penyebab dari terbentur adalah tidak menggunakan safety helmet dan tidak waspada dalam bekerja.

Bahaya kimia dari pekerjaan ini adalah debu semen dan pasir yang dapat menyebabkan gangguan pernapasan.

\section{Pengecoran kolom praktis}

Bahaya mekanis yang terdapat pada pengecoran kolom praktis adalah sama dengan pemasangan bata ringan yaitu terpeleset, terbentur, dan terjatuh. Hal ini dikarenakan area pekerjaan yang sama dan bahan bekerja seperti semen, pasir, dan sebagainya juga masih digunakan.

Bahaya kimia dari pekerjaan ini adalah debu semen dan pasir yang dapat menyebabkan gangguan pernapasan.

\section{Plester}

Bahaya mekanis pada pekerjaan plester juga masih sama yaitu terpeleset, terbentur, dan terjatuh, hal ini juga dikarenakan area kerja yang masih sama.

Bahaya kimia dari pekerjaan ini juga masih sama, yaitu debu semen dan pasir yang dapat menyebabkan gangguan pernapasan.

\section{Pengacian}

Bahaya mekanis pada pekerjaan pengacian juga masih sama dengan plester, pengecoran kolom praktis, dan pemasangan bata ringan, yaitu terpeleset, terjatuh, dan terbentur.

Bahaya kimia dari pekerjaan ini juga masih sama, yaitu debu semen dan pasir yang dapat menyebabkan gangguan pernapasan karena bahan yang digunakan untuk bekerja juga masih sama yaitu semen, pasir, dll.

\section{Hazard Identification Pekerjaan Plumbing Hydrant}

Pekerjaan plumbing hydrant terdiri dari 3 langkah kerja yaitu pengangkatan material, perkitan pipa hydrant, dan pengelasan serta penyambungan pipa hydrant. Masing-masing bahaya yang telah diidentifikasi akan dijelaskan sebagai berikut:

\section{Pengangkatan material}

Pada pengangkatan material terdapat satu bahaya ergonomis dan satu bahaya mekanis, untuk bahaya ergonomis yaitu low back pain yang disebabkan karena posisi kerja yang tidak ergonomis.

Bahaya mekanis yang terdapat ada pengangkatan material adalah terpeleset yang disebabkan karena main frame dalam kondisi licin.

\section{Perakitan perpipaan hydrant}

Perakitan perpipaan hydrant merupakan langkah kerja di mana pekerja rawan terjatuh dan terpeleset, untuk terjatuh dikarenakan cross brace yang tidak sempurna atau tidak lengkap, dan untuk terpeleset dikarenakan main frame dalam kondisi licin. Kedua bahaya tersebut masuk ke dalam bahaya mekanis.

\section{Pengelasan dan penyambungan pipa hydrant}

Pada pengelasan dan penyambungan pipa hydrant terdapat tiga bahaya mekanis dan satu bahaya ergonomis. Bahaya mekanis yang ada yaitu terpeleset yang disebabkan main frame licin, terjatuh yang disebabkan tidak ada penggunaan body harness dan cross brace tidak sempurna, dan yang terakhir terbakar yang disebabkan tidak menggunakan face mask dan safety gloves pada saat pengelasan.

Bahaya ergonomis yang ada yaitu low back pain yang disebabkan karena posisi kerja yang tidak ergonomis (membungkuk).

\section{Hazard Identification Pekerjaan Mechanical Engineering}

Pekerjaan mechanical engineering terdiri dari tiga langkah kerja, yaitu penentuan titik, pemasangan jaringan, dan perakitan kabel. Masing-masing bahaya pada setiap langkah kerjanya adalah sebagai berikut:

\section{Penentuan titik}

Langkah kerja yang pertama adalah penentuan titik, yaitu memetakan tempat di mana jaringan kelistrikan akan dipasang sehingga dapat berfungsi secara maksimal, pemetaan titik ini juga membutuhkan penggunaan scaffolding karena butuh 
naik ke atas mendekati atap. Langkah kerja yang pertama ini mengandung dua bahaya mekanis dan satu bahaya ergonomis.

Bahaya mekanis yang ada yaitu terjatuh yang disebabkan karena main frame yang licin dan tidak menggunakan body harness saat bekerja, serta cross brace tidak terpasang sempurna. Bahaya mekanis yang kedua adalah terbentur yang dikarenakan tidak waspada dan tidak menggunakan safety helmet saat bekerja.

Bahaya ergonomis yang ada pada langkah kerja ini yaitu low back pain yang dikarenakan posisi kerja yang tidak ergonomis.

\section{Pemasangan jaringan}

Langkah kerja yang kedua pada pekerjaan mechanical engineering ini adalah pemasangan jaringan. Pada pemasangan jaringan terdapat dua bahaya mekanis, satu bahaya ergonois, dan satu bahaya fisik yang teridentifikasi.

Bahaya mekanis yang ada yaitu terjatuh yang disebabkan karena main frame licin, cross brace tidak terpasang sempurna, dan tidak menggunakan body harness saat bekerja. Bahaya mekanis yang kedua yaitu terbentur yang dikarenakan tidak waspada dan tidak menggunakan safety helmet saat bekerja.

Bahaya ergonomis pada langkah kerja pemasangan jaringan adalah low back pain yang disebabkan posisi kerja yang tidak ergonomis karena tinggi atap tiga meter dan tinggi scaffolding 1,7 meter, sedangkan tinggi pekerja rata-rata 1,7 meter sehingga pada saat bekerja posisinya sedikit membungkuk.

Bahaya fisik pada langkah kerja ini adalah gangguan pernapasan yang disebabkan oleh debu pada saat pengeboran atap dan pekerja tidak menggunakan respirator.

\section{Perakitan kabel}

Langkah kerja yang terakhir pada pekerjaan mechanical engineering adalah perakitan kabel. Pada perakitan kabel ini terdapat 2 bahaya mekanis dan satu bahaya ergonomis.

Bahaya mekanis pada langkah kerja ini adalah terjatuh yang disebabkan main frame licin, cross brace tidak terpasang sempurna, dan tidak menggunakan body harness saat bekerja. Bahaya mekais yang kedua yaitu terbentur yang dikarenakan tidak waspada dan tidak menggunakan safety helmet saat bekerja.
Bahaya ergonomis pada langkah kerja ini adalah low back pain yang disebabkan posisi kerja yang tidak ergonomis.

\section{Risk Assessment Pekerjaan Struktur}

Pekerjaan struktur memiliki tiga kategori tingkat risiko, yaitu risiko rendah, risiko sedang, dan risiko tinggi yang berasal dari tujuh macam potensi bahaya.

Bahaya mekanis yang terdapat pada pekerjaan finishing yaitu terjepit, tertimpa material, terbentur, tersandung, dan terpeleset. Bahaya ergonomis yang ada yaitu low back pain, dan bahaya fisik berupa kebisingan.

Bahaya terjepit diberikan skor likelihood 4 atau likely karena kemungkinan kejadiannya besar karena disebabkan oleh pekerja yang sering tidak fokus dalam merakit scaffolding $P C H$, untuk severity diberikan skor 2 atau minor karena hanya mengalami cedera ringan dan tidak menimbulkan kerugian finansial yang besar. Hasil perkalian dari likelihood dan severity menggunakan risk matrix didapatkan hasil 8 atau masuk pada kategori risiko sedang yang berarti pekerjaan masih dapat dilanjutkan tetapi dengan pengawasan pihak manajemen yang telah berkonsultasi dengan tim ahli.

Bahaya tertimpa material diberikan skor 4 untuk likelihood atau likely karena kemungkinan kejadian yang besar dikarenakan material yang dalam posisi tidak pas dan cara penanganan yang kurang berhatihati, untuk severity diberikan skor 3 atau moderate karena memerlukan perawatan medis akan tetapi tidak menyebabkan cacat tetap. Hasil perkalian severity dan likelihood menggunakan risk matrix menunjukkan hasil 12 atau kategori risiko tinggi yang berarti pekerjaan harus ditinjau ulang dan dilakukan pengendalian hingga risiko direduksi.

Bahaya terbentur diberikan skor 5 atau almost certain untuk likelihood karena kemungkinan terjadinya yang tinggi yang disebabkan oleh pekerja yang kurang waspada saat bekerja, untuk severity diberikan skor 1 atau insignificant karena tidak menimbulkan cedera dan tidak ada hari kerja yang hilang. Hasil perkalian severity dan likelihood menggunakan risk matrix untuk bahaya terbentur menghasilkan skor 5 atau kategori risiko sedang yang berarti pekerjaan hanya dapat dilanjutkan dengan pengawasan dari pihak manajemen yang telah berkonsultasi dengan tim ahli.

Bahaya terpeleset memiliki skor likelihood 3 atau possible yang berarti mungkin terjadi apabila 
ada faktor tambahan yaitu lantai yang licin karena genangan air setelah pengecoran, untuk severity diberikan skor 2 atau minor karena terjadi cedera ringan dan memerlukan pertolongan pertama karena apabila terpeleset mungkin saja bagian tubuhnya terbentur material yang menyebabkan cedera ringan. Hasil perkalian likelihood dan severity menggunakan risk matrix menunjukkan hasil 6 yang berarti masuk pada kategori risiko sedang yang berarti pekerjaan hanya dapat dilanjutkan dengan syarat diawasi secara khusus oleh pihak manajemen dan sudah berkonsultasi dengan tim ahli.

Bahaya tersandung memiliki skor likelihood 4 atau likely karena kemungkinan kejadiannya besar yang disebabkan kurang waspada dan penempatan material yang berserakan, untuk severity diberikan skor 1 atau insignificant karena tidak menimbulkan cedera dan tidak menyebabkan hilangnya hari kerja. Hasil perkalian severity dan likelihood dari bahaya tersandung menggunakan risk matrix menghasilkan nilai 4 yang masuk pada kategori risiko rendah yang berarti risiko masih dapat diterima namun tetap diusahakan untuk mengurangi risiko apabila masih mungkin untuk direduksi.

Bahaya low back pain memiliki skor likelihood 5 atau almost certain yaitu mungkin terjadi dalam semua keadaan normal karena posisi kerja yang tidak ergonomis, untuk severity diberikan skor 1 atau insignificant karena tidak menimbulkan cedera dan tidak hilang hari kerja. Hasil perkalian likelihood dan severity dari bahaya low back pain menggunakan risk matrix menunjukkan hasil 5 yang masuk pada kategori risiko sedang, ini berarti pekerjaan hanya dapat dilanjutkan dengan keputusan manajemen yang tepat dan telah berkonsultasi dengan tim ahli.

Bahaya fisik yang ada pada pekerjaan struktur yaitu kebisingan yang terjadi karena suara material scaffolding $P C H$ yang berjatuhan saat pembongkaran. Skor likelihood untuk bahaya kebisingan adalah 5 atau almost certain karena hampir terjadi pada setiap keadaan, untuk severity diberikan skor 1 atau insignificant karena tidak menimbulkan cedera dan tidak membutuhkan perawatan serta tidak menyebabkan hilangnya hari kerja. Hasil perkalian likelihood dan severity menggunakan risk matrix menunjukkan hasil 5 atau masuk dalam kategori risiko sedang yang berarti pekerjaan hanya dapat dilanjutkan dengan keputusan manajemen yang tepat dan telah berkonsultasi dengan tim ahli.

Semua hazard diatas dapat terjadi karena proyek ini tidak memenuhi persyaratan teknis seperti tidak adanya scaffolder khusus yang telah disertifikasi oleh Kemenaker, tidak layaknya scaffolding yang digunakan dan terjadi karena faktor alamiah seperti ketinggian dari bangunan dan lingkungan sekitar seperti debu.

\section{Risk Assessment Pekerjaan Finishing}

Pekerjaan finishing memiliki satu kategori tingkat risiko, yaitu risiko sedang yang berasal dari empat macam potensi bahaya.

Bahaya mekanis yang terdapat pada pekerjaan finishing yaitu terpeleset, terjatuh dan terbentur, sedangkan bahaya ergonomis yang terdapat pada pekerjaan ini adalah gangguan pernapasan yang disebabkan oleh debu.

Bahaya terpeleset diberikan skor likelihood sebesar 3 atau possible karena ada kemungkinan terjadi bila terdapat faktor tambahan, faktor tambahan di sini adalah platform yang licin karena terkena semen, untuk severity diberikan skor 2 atau minor karena cedera yang mungkin terjadi adalah ringan asalkan tidak sampai terjatuh ke bawah. Hasil perkalian severity dan likelihood yaitu 6 yang masuk pada kategori risiko sedang yang berarti pekerjaan masih dapat dilanjutkan tetapi dengan pengawasan pihak manajemen yang telah berkonsultasi dengan tim ahli.

Bahaya terjatuh memiliki skor likelihood sebesar 2 atau unlikely karena kejadian termasuk langka terjadi pada pekerjaan finishing, untuk severity diberikan skor 4 atau major karena apabila terjadi maka dapat menimbulkan cedera parah, kecacatan tetap, atau bahkan kematian, hal ini bergantung dari ketinggian lokasi jatuhnya pekerja. Hasil dari perkalian likelihood dan severity yang dilihat pada risk matrix menunjukkan angka 8 atau masuk pada kategori risiko sedang yang berarti pekerjaan hanya dapat dilanjutkan dengan keputusan manajemen yang tepat dan setelah berkonsultasi dengan tim ahli.

Bahaya terbentur memiliki skor likelihood 5 atau almost certain karena dapat terjadi pada setiap keadaan yang dikarenakan kurang waspadanya pekerja dan diperparah dengan tidak menggunakan safety helmet, untuk severity diberikan skor 1 atau insignificant karena tidak menimbulkan cedera, tidak memerlukan perawatan dan tidak menyebabkan hilangnya hari kerja. Hasil perkalian antara likelihood dan severity menggunakan risk matrix didapatkan hasil 5 yang masuk pada kategori risiko sedang yang berarti pekerjaan hanya dapat 
dilanjutkan dengan keputusan manajemen yang tepat dan setelah berkonsultasi dengan tim ahli.

Bahaya gangguan pernapasan memiliki skor likelihood sebesar 5 atau almost certain karena dapat terjadi pada setiap keadaan yang disebabkan karena debu semen dan pasir yang pasti ada pada pekerjaan finishing, untuk severity didapatkan skor 1 atau insignificant karena tidak menimbulkan cedera, tidak membutuhkan perawatan dan tidak menyebabkan hilangnya hari kerja. Hasil perkalian likelihood dan severity yang didapat dari risk matrix menunjukkan hasil 5 yang masuk pada kategori risiko sedang yang berarti pekerjaan hanya dapat dilanjutkan dengan keputusan manajemen yang tepat dan setelah berkonsultasi dengan tim ahli.

\section{Risk Assessment Pekerjaan Plumbing Hydrant}

Pekerjaan plumbing hydrant memiliki satu kategori tingkat risiko, yaitu risiko sedang yang berasal dari empat macam potensi bahaya.

Bahaya yang terdapat pada pekerjaan plumbing hydrant terdiri dari tiga bahaya mekanis dan satu bahaya ergonomis. Bahaya mekanis yang ada yaitu terpeleset, terjatuh, dan terbakar, sedangkan bahaya ergonomis yang ada yaitu low back pain.

Bahaya terpeleset memiliki nilai likelihood sebesar 3 atau possible karena dapat terjadi apabila ada faktor tambahan, yaitu main frame yang licin, untuk severity diberikan nilai 2 atau minor karena menyebabkan cedera ringan dan membutuhkan pertolongan pertama. Hasil perkalian dari likelihood dan severity menggunakan risk matrix menunjukkan hasil 6 yaitu berada pada kategori risiko sedang yang berarti pekerjaan hanya dapat dilanjutkan dengan keputusan manajemen yang tepat dan setelah berkonsultasi dengan tim ahli.

Bahaya terjatuh memiliki nilai likelihood sebesar 2 atau unlikely karena kemungkinan terjatuh langka pada pekerjaan plumbing hydrant, sedangkan nilai severity diberikan nilai 4 atau major karena dapat menimbulkan cedera parah, cacat tetap, atau kematian apabila terjadi, tetapi hal ini relatif tergantung kepada ketinggian lokasi jatuhnya pekerja. Hasil perkalian likelihood dan severity pada bahaya terjatuh ini apabila dilihat pada risk matrix ini bernilai 8 yang berarti masuk kepada kriteria risiko sedang yang berarti pekerjaan hanya dapat dilanjutkan dengan keputusan manajemen yang tepat dan setelah berkonsultasi dengan tim ahli.

Bahaya terbakar memiliki nilai likelihood sebesar 4 atau likely dimana kemungkinan kejadian besar dikarenakan tidak menggunakan face mask dan safety gloves, untuk severity bernilai 2 atau minor karena cedera ringan karena percikan las yang membutuhkan pertolongan pertama dan kerugian finansial yang tergolong kecil. Hasil perkalian antara likelihood dan severity pada bahaya terbakar apabila dilihat pada risk matrix menunjukkan angka 8 yang masuk pada kategori risiko sedang, hal ini berarti pekerjaan hanya dapat dilanjutkan dengan keputusan manajemen yang tepat dan setelah berkonsultasi dengan tim ahli.

Bahaya low back pain memiliki nilai likelihood 5 atau almost certain karena posisi yang selalu dalam keadaan tidak ergonomis, untuk nilai severity sebesar 1 atau insignificant karena tidak menimbulkan cedera, tidak menimbulkan kerugian finansial, dan tidak menyebabkan hilangnya hari kerja. Hasil perkalian dari likelihood dan severity bahaya low back pain apabila dilihat pada risk matrix menunjukkan angka 5 atau berada pada kategori risiko sedang yang berarti pekerjaan hanya dapat dilanjutkan dengan keputusan manajemen yang tepat dan setelah berkonsultasi dengan tim ahli.

\section{Risk Assessment Pekerjaan Mechanical Engineering}

Pekerjaan mechanical engineering memiliki satu kategori tingkat risiko, yaitu risiko sedang yang berasal dari empat macam potensi bahaya.

Bahaya yang terdapat pada pekerjaan mechanical engineering terdiri dari dua bahaya mekanis, satu bahaya ergonomis dan satu bahaya fisik. Bahaya mekanis yang ada yaitu terjatuh dan terbentur, sedangkan bahaya ergonomis yang ada yaitu low back pain, dan bahaya fisik yang ada yaitu gangguan pernapasan yang disebabkan oleh debu.

Bahaya terjatuh memiliki nilai likelihood sebesar 2 atau unlikely di mana bahaya ini langka terjadi pada pekerjaan mechanical engineering selama proyek ini dilaksanakan, untuk nilai severity yaitu 4 atau major karena menyebabkan cedera berat, kerugian finansial besar, dan hilangnya hari kerja. Hasil perkalian likelihood dan severity menggunakan risk matrix menunjukkan nilai 8 di mana masuk pada kategori risiko sedang yang berarti pekerjaan hanya dapat dilanjutkan dengan keputusan manajemen yang tepat dan setelah berkonsultasi dengan tim ahli.

Bahaya terbentur memiliki nilai likelihood sebesar 5 atau almost certain karena kemungkinan kejadiannya yang hampir terjadi pada setiap keadaan yang disebabkan pekerja yang tidak waspada dan tidak menggunakan safety helmet, untuk nilai 
severity sebesar 1 atau insignificant karena tidak menyebabkan cedera dan tidak menyebabkan hilangnya hari kerja. Hasil perkalian severity dan likelihood menggunakan risk matrix didapatkan hasil sebesar 5 atau masuk pada kategori risiko sedang yang berarti pekerjaan hanya dapat dilanjutkan dengan keputusan manajemen yang tepat dan setelah berkonsultasi dengan tim ahli.

Bahaya low back pain memiliki nilai likelihood sebesar 5 atau almost certain karena posisi kerja yang tidak ergonomis dapat terjadi pada setiap keadaan, untuk severity didapatkan nilai sebesar 1 atau insignificant karena tidak menimbulkan cedera dan tidak menimbulkan hilangnya hari kerja. Hasil perkalian likelihood dan severity menggunakan risk matrix didapatkan hasil sebesar 5 atau masuk pada kategori risiko sedang yang berarti pekerjaan hanya dapat dilanjutkan dengan keputusan manajemen yang tepat dan setelah berkonsultasi dengan tim ahli.

Bahaya gangguan pernapasan memiliki nilai likelihood sebesar 5 atau almost certain karena debu pada saat pemasangan jaringan berasal dari pengeboran atap dan ini terjadi pada setiap keadaan, untuk nilai severity didapatkan nilai 1 atau insignificant karena tidak menyebabkan cedera dan tidak menyebabkan hilangnya hari kerja. Hasil perkalian likelihood dan severity didapatkan hasil sebesar 5 yang masuk pada kategori risiko sedang yang berarti pekerjaan hanya dapat dilanjutkan dengan keputusan manajemen yang tepat dan setelah berkonsultasi dengan tim ahli.

\section{Kategori Risiko yang Paling Dominan}

Kategori risiko yang paling dominan berdasarkan hasil risk assessment pada pengoperasian scaffolding PT. X yaitu risiko sedang sebesar $93 \%$, untuk urutan kedua yaitu risiko tinggi sebesar $5 \%$, dan terakhir risiko rendah sebesar $2 \%$ dari seluruh potensi bahaya yang ada. Hal ini menunjukkan bahwa sebagian besar pekerjaan yang menggunakan scaffolding berada pada risiko sedang yang berarti pekerjaan hanya dapat dilakukan dalam keputusan manajemen yang tepat, selain itu manajemen harus lebih fokus dalam pengendalian dan pengawasan pekerja untuk mereduksi risiko yang ada menjadi dominan pada kategori risiko rendah, akan tetapi yang menjadi prioritas tetap bahaya yang berisiko tinggi, dikarenakan yang paling mungkin menimbulkan kecelakaan adalah yang berisiko tinggi.
Pengendalian yang paling mungkin dilakukan adalah pengendalian yang menyangkut likelihood, karena likelihood lebih mungkin untuk dikendalikan menjadi skor yang lebih rendah daripada apabila mengendalikan severity.

\section{SIMPULAN}

Risiko yang paling dominan yang didapat dari hasil risk assessment pada pengoperasian scaffolding PT. X yaitu risiko sedang yang berjumlah 40 potensi bahaya atau $93 \%$ dari seluruh potensi bahaya yang ada, untuk itu sebagian besar pekerjaan hanya dapat dilanjutkan dan peralatan hanya dapat digunakan dengan keputusan manajemen yang tepat setelah berkonsultasi dengan tenaga ahli dan tim penilai.

Risiko tertinggi dalam pengoperasian scaffolding adalah kategori risiko tinggi yaitu 5\% dari seluruh bahaya dan hal ini menjadi prioritas pengendalian dan harus segera diturunkan ke kategori risiko rendah.

Pengendalian pada risk assessment yang paling mungkin dilakukan adalah pengendalian terhadap kemungkinan daripada keparahan karena pengendalian terhadap kemungkinan berhubungan dengan pengendalian potensi terjadinya bahaya dan kecelakaan.

Hal yang paling mungkin dilakukan adalah menjalankan perawatan berkala terhadap scaffolding untuk mengurangi kemungkinan terjadinya kecelakaan.

\section{DAFTAR PUSTAKA}

British Standard Institute. Occupational Health and Safety Assessment (OHSAS) 18001:2007. 2007. England.

Dirjen PPK. 2004. Surat Keputusan Dirjen PPK No. 20/DJPPK/2004 Tentang Sertifikasi Kompetensi Keselamatan dan Kesehatan Kerja Bidang Konstruksi Bangunan. Jakarta.

Kemenaker R.I. 1980. Permenaker No. 01/Men/1980 tentang keselamatan dan kesehatan kerja pada konstruksi bangunan. Jakarta.

Persada, Y. B. 2015. Hazard Identification and Risk Assessment (HIRA) Kecelakaan Kerja pada Proses Pengoperasian Scaffolding (Studi pada Proyek Apartemen PT. X di Surabaya). Skripsi. Fakultas Kesehatan Masyarakat Universitas Airlangga. Surabaya.

Prasetiyo, M.G.D. 2009. Gambaran Tingkat Risiko Bahaya Keselamatan Pekerja Kontraktor yang 
Menggunakan Scaffolding pada Renovasi Gedung PAU di Universitas Indonesia Tahun 2009. Skripsi. Fakultas Kesehatan Masyarakat Universitas Indonesia. Depok.

Pratiwi, S.D. 2009. Tinjauan Faktor-Faktor Perilaku Kerja Tidak Aman pada Proyek Pembangunan GOR Boker Ciracas PT. Waskita Karya Tahun 2009. Skripsi. Fakultas Kesehatan Masyarakat Universitas Indonesia. Depok.

Ramli, S. 2010. Pedoman Praktis Manajemen Risiko dalam Perspektif K3 OHS Risk Management. Cetakan Pertama. Dian Rakyat. Jakarta.
Susihono, W dan F. . Rini. 2013. Penerapan Sistem Manajemen Keselamatan dan Kesehatan Kerja (K3) dan Identifikasi Potensi Bahaya Kerja (Studi Kasus di PT. LTX Kota Cilegon- Banten). Jurnal Spektrum Industri 11(2): 117-242.

Wahyuni, I. 2010. Sistem Pengendalian Bahaya Bekerja pada Ketinggian dalam Upaya Pencegahan.

Kecelakaan Kerja di PT. Gunanusa Utama Fabricators Serang Banten. Laporan Khusus. Program Diploma III Hiperkes dan Keselamatan Kerja. Surakarta. 